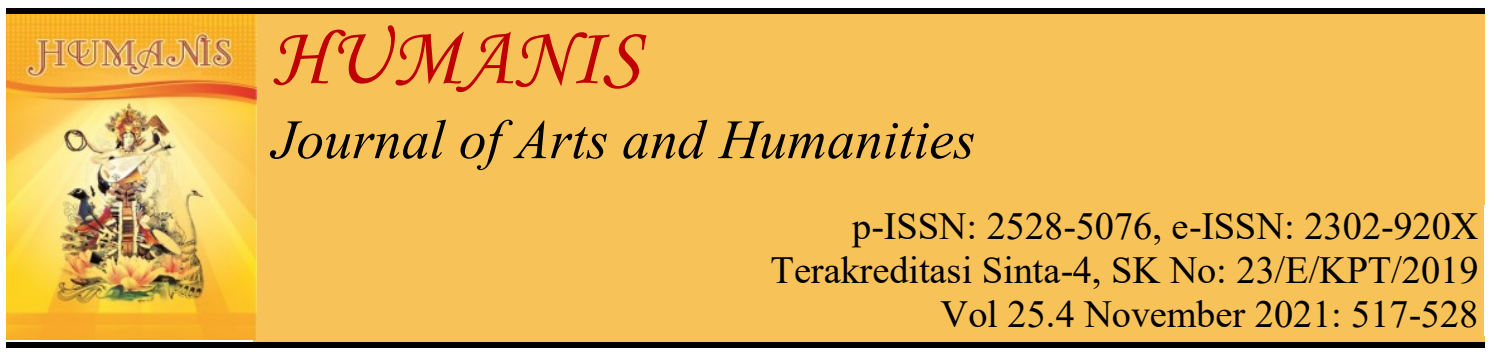

\title{
Ijtihad Kemanusiaan MDMC dalam Menghadapi Pandemi Covid-19 di Indonesia
}

\author{
Hasan Sadikin Muis \\ Institut Teknologi dan Bisnis-Ahmad Dahlan Jakarta \\ Jakarta Selatan, Provinsi DKI Jakarta \\ Email korespondensi: sadikin@upi.edu
}

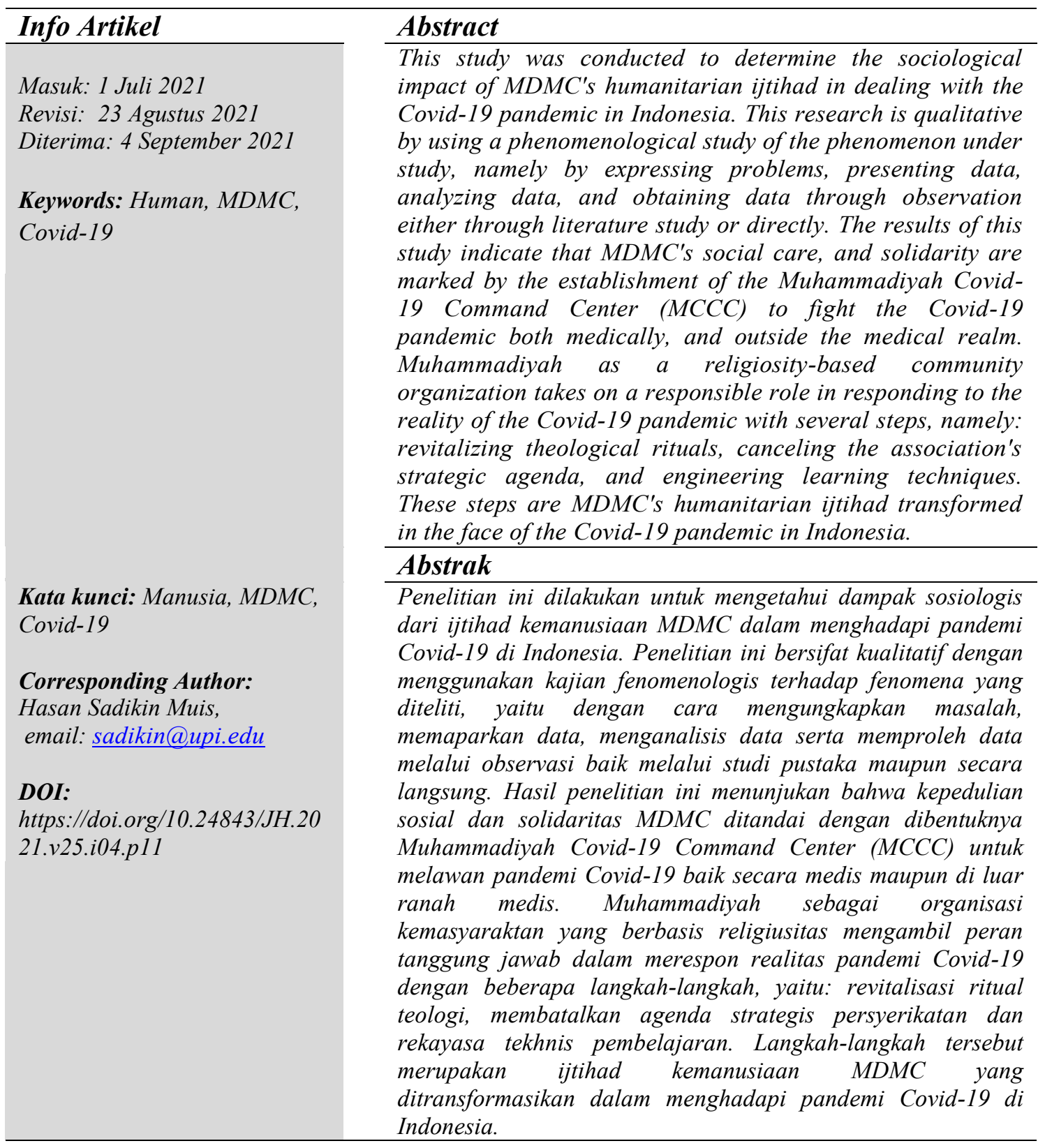




\section{PENDAHULUAN}

Perjuangan terberat dalam penanggulangan Covid-19 bukan pada penanganan pasien yang terpapar tetapi pada edukasi bahwa wabah pandemi Covid-19 belum usai. Sebagian masyarakat bahkan sudah tidak lagi percaya bahwa pandemi Covid-19 ini benar adanya. Perlahan-lahan, pandemi Covid-19 telah merubah pola hidup manusia di segalah sektor kehidupan (Zainab, 2020). Sampai sekarang, belum bisa pastikan kapan polah hidup semacam ini akan berakhir. Satu-satunya yang bisa diprediksi adalah kesadaran masyarakat terhadap virus ini dalam mematuhi protokol kesehatan. Dalam memutuskan rantai penyebaran Covid-19, diperlukan kesadaran masyarakat tentang bahanya terpapar Covid-19 (Ervianingsih et al., 2020). Kendati sempat menjadi kritikan didalam merumuskan kebijakan, apakah karantina wilayah yang lebih efektif dalam memutuskan rantai penyebaran Covid-19 ataukah dengan mengambil lahkah penerapan lockdown secara total (Junaedi, 2020). Pada masa pandemi tanggung jawab kebersamaan benar-benar diuji. Sebab ketidak pedulian terhadap virus ini sama dengan mencelakakan diri sendiri dengan orang lain. Meskipun telah memasuki kondisi new normal, masyarakat harus tetap mewaspadai dan masih akan berlanjut bila tatanan baru yang ada tidak dipatuhi (Miharja et al., 2020). Pada fase inilah, dianjurkan untuk saling menyelamatkan dan menjadi tanggung jawab kolektif. Tanpa kesadaran kolektif akan semakin banyak yang terpapar dan semakin sulit ruang publik dikendalikan.

Kasus pandemi Covid-19 dan kondisi psikososial masyarakat harus dipahami sebagai fakta sosial bukan hanya sekedar fakta evolusi biologis. Dalam upaya menghindari interaksi sosial dan penyebaran Covid-19 tergantung pola kesadaran masyarakat dalam melihat bahanyanya penularan Covid-19 (Farizah \& Kusuma, 2020). Sebagai fakta sosial bisa dicermati dengan seluruh variabel kehidupan. Terlalu luas dan besar untuk diuraikan tentang fakta sosial dan dampak pandemi Covid-19 bagi tatanan sosial masyarakat. Fakta sosial pandemi Covid-19 telah mempengaruhi berbagai dimensi kehidupan dan mempengaruhi prilaku masyarakat terhadap keberlanjutan pandemi Covid-19 ini. Salah satu dari dampak pandemi Covid-19 adalah kemerosotan dalam dunia bisnis dan ekonomi (Hawangga \& Sutama, 2020). Bila efek pandemi Covid-19 ini berpengaruh pada sisi positif maka akan mempengaruhi percepatan rekonstruksi ruang publik terutama meminimalkan korban. Namun sebaliknya, sisi negatif dapat memperpanjang masa pandemi dan menambah jumlah korban positif maupun dampak terhadap keberlangsungan hidup masyarakat. Kondisi semacam ini, mendesak pemerintah untuk mengambil langkah kebijakan strategis untuk memaksimalkan ruang publik yang tercemar akibat Covid-19 (Hanoatubun, 2020).

Pandemi Covid-19 belum bisa prediksi sampai kapan akan berakhir, kejadian kasus demi kasus tidak pernah jedah di setiap hari. MDMC sebagai lembaga penanggulangan bencana mengambil beberapa peran terkait proses misi kemanusiaan dalam rangka untuk menangani pandemi Covid-19 ini. Kegiatan yang dilaksanakan berupa pembagian paket sembako, penyemprotan disinfektan dan sosialisasi mengenai protokol atau tata cara tindakan terhadap Covid-19 di dalam lingkungan masyarakat. Sosialisasi standar protokol yang dilakukan MDMC sebagaimana yang dilakukan oleh pemerintah yaitu membumikan misi kemanusiaan di tengah lesuh daya sehat masyarakat. Penanganan lain juga dilakukan dari sisi 
edukasi dalam upaya memberikan penyadaran terhadap masyarakat akan pentingnya meningkatkan kesadaran bersama serta bagaimana cara menghindari Covid-19 dari sisi penjagaan diri terutama edukasi mengenai protokol Covid-19. Hal itulah yang dilakukan oleh MDMC dan MCCC di seantero Indonesia dengan mengkapitalisasi jaringan Muhammadiyah di amal usaha untuk meminimalkan curva Covid-19 di seluruh penjuruh tanah air.

Pertumbuhan kurva kasus wabah pandemi Covid-19 terus meningkat. Hal ini membuat reaksi kecemasan masyarakat semakin meningkat pula hingga berujung pada penolakan terhadap jenazah pasien Covid-19. Disamping itu, kecemasan autentik juga dialami oleh para tenaga kesehatan, akibat kelangkaan Alat Perlindungan Diri (ADP) yang dibutuhkan dalam upaya penanganan COVID-19 (Husein, 2020). Mengamati dampak sosiologis yang ditimbulkan oleh Covid-19 menunjukan bahwa pemerintah harus dibantu dalam upaya menangani pandemi Covid-19 ini (Muchlasin \& Suyatno, 2020). Sebagai organisasi Islam, Muhammadiyah menganggap bahwa pandemi Covid-19 adalah tanggung jawab kolektif seluruh elemen civil society di Indonesia, tidak hanya dibebankan kepada pemerintah. Dari awal pertumbuhan kasus pandemi Covid19 di Indonesia, Muhammadiyah turut berperan aktif dalam membantu pemerintah guna untuk mempercepat respons melalui kerja sama dengan beberapa lembaga pemerintah. Dalam upaya untuk menangani kecemasan masyarakat dan tenaga kesehatan tersebut, MCCC membukan Layanan Dukungan Psikososial (LDP) psikolog. Kendati MCCC merupakan lembaga ad hoc ormas islam, namun ruang pelayanan publik meliputi seluruh elemen masyarakat tanpa terkecuali (Muryanti, 2020). Layanan psikologi tersebut merupakan konsultasi psikis secara online yang dilayani oleh 60 psikolog Muhammadiyah dan Aisyiyah yang ditugaskan sebagai tempat konsultasi masyarakat yang mengalami kecemasan.

Dampak yang paling fundamental dari pandemi Covid-19 adalah dampak ekonomi, kendati dampak yang lain juga ikut berpengaruh di dalam variabel pandemi. Dampak ekonomi sangat dirasakan langsung oleh masyarakat secara keseluruhan, terutama masyarakat mata pencahariannya dilakukan secara mandiri atau hanya bergantung pada perusahan-perusahan menengah kebawah yang mengalami penurunan produksi. Pimpinan Pusat Muhammadiyah menganjurkan untuk tetap mawas diri dengan terus memaksimalkan ikhtiar dalam upaya mempertahan kelangsungan hidup di tengan daya beli menurut (Hanafi, 2020). MCCC juga berupaya untuk menghadirkan beberapa langkalangkah untuk mendapatkan solusi atas problem ini seperti melakukan kerja-kerja inovatif misalkan membuat kontenkonten yang kreatif, ekonomi digital yang bisa mendapatkan pemasukan bagi masyarakat. Struktur kepengurusan Muhammadiyah dari pusat hingga ranting digerakan untuk berperan aktif membentuk MCCC (Junaedi, 2020). Hal itulah yang dilakukan oleh Muhammadiyah untuk membangkitkan ekonomi masyarakat dengan memanfaatkan informasi dan teknologi yang sedang berkembang. Dampak ekonomi akibat Covid-19 ini, masyarakat hampir tidak mendapatkan akses yang banyak untuk memproleh atau mendapatkan ekonomi secara mandiri. Karena itu, butuh tindakan emergency yang bisa mengurangi dampak ekonomi melalui distribusi sembako yang dilakukan secara langsung dengan turun ke lapangan untuk mendistribusikan paket sembako bersama MCCC dan Lazismu. 
Penanganan Covid-19 di Indonesia masih terus berlangsung dengan laju penyebaran belum bisa dikendalikan. Dalam pandangan Muhammmadiyah harus disikapi dengan tetap mengikuti standar protokol kesehatan secara ketat, dengan menerapkan $5 \mathrm{M}$ yang telah dianjurkan untuk membantu pencegahan penularan virus corona, yaitu: mencuci tangan, memakai masker, menjaga jarak, menjauhi kerumunan dan mengurangi mobilitas. Mengingat statistik angka penderitaan Covid-19 setiap hari terus bertambah serta tidak menunjukan penurunan yang signifikan. Karena itu, Muhammadiyah melalui kordinasi terpusat MCCC terus melaksanakan pelayanan dalam upaya untuk mencega penularan atau penderintaan Covid-19 ini. Semua program dan aksi filantropi Muhammadiyah dalam penanganan Covid-19 tentunya berdampak positif bagi masyarakat luas (Ichsan, 2020). Edukasi tentang pandemi Covid-19 tetap terus dilakukan dengan kemampuan yang ada dan antisipasi dampak ekonomi Covid-19 akan dilakukan melalui program ketahanan pangan.

Dalam kasus pandemi Covid-19, Muhammadiyah telah menggerakan seluruh elemen di dalam ruang lingkup persyarikatan dalam menopang kekuatan negara dengan cara membantu pemerintah di dalam upaya pencegahan. Langkah organisasi Muhammadiyah menunjukkan sikap tanggung jawab kolektif seluruh elemen civil society dalam merespons wabah (Alkaf, 2020). Transformasi sosial yang dilakukan MDMC merupakan gerakan bersama dalam upaya melawan Covid-19 melalui gerakan masker, jaga jarak dan cuci tangan. Kesalehan sosial adalah adalah orang yang secara sosial besama-sama mengajak masyarakat untuk sama-sama memaksimalkan akal sehat dan meminimalkan akal bulus. MDMC yang didirikan oleh Pimpinan Pusat
Muhammadiyah dalam upaya membantu masyarakat untuk bersama-sama melakukan kesalehan sosial secara berjamaah. Kaidah pokok yang dipakai Muhammadiyah bersumber pada AlQur'an dan Hadis dengan kombinasi perkembangan science modern yang dilakukan secara komperhenship (Falahuddin, 2020). Di samping itu, peranan akal dalam memahami teks dapat diterima sepanjang tidak bertentangan dengan dhahiral-nash serta diselesaikan dengan tawil. Metode bayani (semantic), ta"lili (rasionalistik) dan istislahi (filosofis) menjadi metode yang kerap digunakan dalam menentukan hukum (Insya' \& Ulumuddin, 2020).

Dalam hal metode penetapan hukum, Muhammadiyah merumuskan beberapa Metode Tarjih antara lain:

1) ber-istidlal dengan dasar utama alQur'an dan al-hadis

2) Ijtihad dan istimbat

3) Ijtihad menggunakan system ijtihad jama"iy.

4) Tidak mengikat pada salah satu madzhab, namun sebagian pendapatpendapat Madzhab bias menjadi bahan pertimbangan dalam menentukan hukum.

5) Majelis Tarjih mempunyai prinsip toleran dan terbuka dalam menerima kritik dan saran.

6) Menggunakan ijma" shahaby sebagai dasar.

7) Menggunakan al-jam" $u$ wa al-taufiq dalam menghadapi dalil yang nampat terjadi al-ta" arud.

MDMC dalam kaitannya dengan konsep kebencanaan tidak akan perna lepas dari apa yang telah diformulasikan oleh majelis tarjih dalam fiqih kebencanaan. Bahwa setiap kejadian merupakan hak Allah SWT atas keterlibatan manusia. Dalam pemahaman seorang yang berketuhanan, MDMC dan MCCC telah berupaya melakukan 
gerakan-gerakan kemanusia dalam konteks pencegahaan. Sehingga masyarakat dapat memahami bahwa manusia yang terpapar Covid-19 merupakan akibat dari kelalaian dalam memaksimalkan protokol kesehatan. Pandemi Covid-19 telah merubah wajah peradaban dunia. Perubahan pola hidup dan aktivitas kerja baik secara horizontal maupun vertikal. Demikian juga ritual keagamaan yang semulah diwajikan diselenggarakan masjid kini dilaksanakan di rumah masing-masing. Sehubungan dengan perubahan pelaksanaan ritual keagamaan tersebut, Pimpinan Pusat Muhammadiyah mengeluarkan fatwa tentang pentingnya menjaga dan mengutamakan kemaslahatan bersama dengan menjauhkan mudharat.

\section{METODE DAN TEORI}

Pendekatan yang digunakan di dalam penelitian ini adalah dengan menggunakan pendekatan kulitatif. Metode pendekatan ini dimaksudkan untuk memudahkan peneliti dalam merumuskan narasi penelitian untuk disesuaikan dengan masalah penelitian yang dihadapi, yaitu memahami patologi sosial yang berhubungan dengan ijtihad kemanusiaan MDMC dalam menghadapi gelombang virus Covid-19 di Indoensia. Penggunaan metode pendekatan kualitatif diharapkan dapat mengeksplorasi secara dalam serta memahami secara holistik dampak sosiologis dari pengaruh ijtihad kemanusiaan MDMC. Bagi Creswell (2012:31) pendekatan kualitatif dapat menjawab permasalahan-permasalahan yang oleh peneliti tidak menyadari variabelvariabelnya sehingga diperlukan eksplorasi.

Jenis penelitian ini bermuara pada tafsiran fenomenologis yang mempunyai brand tersendiri dengan fenomena yang diteliti, yaitu dengan cara mengungkapkan masalah, memaparkan data, menganalisis data serta memproleh data melalui observasi, wawancara dan dokumentasi baik melalui studi pustaka maupun secara langsung. Subjek penelitian adalah pengurus dan relawan MDMC yang terlibat dalam upaya rekonstruksi ruang publik di tengan pandemi Covid-19 di Indonesia. Prosedur penelitian dilakukan dengan menentukan masalah yang akan dibahas yaitu ijtihad kemanusiaan MDMC dalam menghadapi pandemi Covid-19 di Indonesia. Data dikumpulkan melalui observasi, wawancara, studi pustakan dan dokumentasi, kemudian diformulasikan dengan merumuskan hasil penelitian sebagai bentuk tercapainya penelitian.

Penelitian ini bertujuan mewujudkan hasil penelitian yang kritis dan ilmiah mengenai ijtihad kemanusiaan MDMC dalam menghadapi pandemi Covid-19 di Indonesia. Untuk mencapai tujuan itu maka digunakan alat-alat analisis, yakni konsep dan teori yang relefan. Dalam kaitan dengan penelitian ini, teori perkembangan ruang publik (Habermas, 1989:36-37) digunakan sebagai landasan dengan asumsi dasar bahwa ruang publik mempunyai tiga konsepsi yang dianggap sebagai ruang publik masyarakat. a). Mengutamakan prinsip-prinsip egaliter sebagai spirit didalam perjuampaan diantara mereka dengan mengesampingkan disparitas sosial. b). Public discourse membuka tema-tema yang dianggap tabu untuk didiskusikan seperti monopoli negara dan gereja atas interpretasi kebenaran dalam teks. c). Perjumpaan individu di dalam ruang publik sastra telah mengubahkebudayaan menjadi komoditas.

\section{HASIL DAN PEMBAHASAN}

Dalam merespon realitas kemanusian global, seorang warganegara yang demokratis harus menyikapi musibah dengan memperlihatkan sikap kepedulian 
sosial dan solidaritas. Hal ini merupakan manifestasi dari kesalehan sosial MDMC yang ditransformasikan dalam merekonstruksi ruang publik di tengah kelesuhan daya beli masyarakat. Kepedulian sosial dan solidaritas MDMC ditandai dengan dibentuknya MCCC untuk melawan pandemi Covid-19 baik secara medis maupun di luar ranah medis yang meliputi relawan distributor alat pelindung diri (ADP), relawan distributor sandang dan pangan, relawan pengemudi dan lain-lain. Kepedulian sosial dan solidaritas ini dapat dimaknai dalam bentuk gotong royong untuk menangani gelombang virus Covid-19 di Indonesia. Wabah pandemi Covid-19 ini bukan hanya tanggung jawab pemerintah semata, Muhammadiyah sebagai organisasi kemasyaraktan yang berbasis religiusitas mengambil peran tanggung jawab dalam merespon realitas pandemi Covid-19. Semua kalangan tanpa harus membedakan suku, ras, agama harus mengambil bagian dalam merespon realitas kemanusiaan ini. Semakin berat bila dibebankan kepada pemerintah semata dalam menangganinya. Diperlukan sikap gotong royong dan semangat kebersamaan untuk menyelesaikan setiap persoalan dalam menghadapi ancaman pandemi Covid-19.

Misi kemanusiaan harus ditempatkan pada posisi yang paling tinggi sebagai prioritas utama dalam semua ruang kehidupan. Tanpa ada rasa kemanusiaan, manusia tidak akan bisa bertahan hidup kendati menguasai seluruh properti dunia dan seisinya. Karena itu, negara harus memandang misi kemanusiaan sebagai prioritas utama untuk setiap pengambilan kebijakan. Kadang misi kemanusiaa itu diabaikan, atau misi ekonomi mendahului misi kemanusiaan dalam pengambilan kebijakan, seperti pelonggaran Pembatasan Sosial Berskala Besar (PSBB). MDMC dari awal memprotes kebijakan ini, sebab menggeserkan misi kemanusiaan dari agenda politik. Itu sebabnya, setiap kebijakan pemerintah yang tidak memasuiki variabel kemanusiaan, selalu mendapatkan kritikan. Bahkan di dalam persyerikatan Muhammadiyah, dituntut untuk konsisten dalam membumikan misi kemanusiaan universal. Sebab misi kemanusiaan sangat linear dengan misi yang lainnya. Bila misi kemanusiaan tidak didahulukan, maka misi yang lainnya akan terbengkelai. Salah satu contoh yang paling autentik adalah ketika kebijakan melonggarkan PSBB diterapkan dengan mengabaikan perkembangan statistik covid-19 yang terus melaju. Secara tidak langsung, negara telah mengabaikan misi kemanusiaan dengan mendahului kepentingan ekonomi, termasuk proses belajar mengajar di sekolah-sekolah yang ingin dinormalkan kembali dan pelaksanakan ibadah yang cenderung mengabaikan kaidah-kaidah misi kemanusiaan.

Covid-19 menciptakan krisis yang luar biasa secara global. Kondisi global saat ini tidak bisa dianggap sebelah mata. Secara kemanusiaa akan ada krisis yang sangat luar biasa, orang-orang bisa mengalami depresi selain korban jiwa yang sama-sama telah diketahui. Kendati vaksinasi sedang berlangsung, dan penerapan PPKM (Perberlakukan Pembatasan Kegiatan Masyarakat) darut dilakukan secara ketet, tingkat kematian pasien corona di Indonesia pada hari Selasa 20 Juli 2020 kembali tercatat sebagai angka tertinggi dibandingkan dengan negara-negara lain di seluruh dunia (https://nasional.kontan.co.id). Hal ini akan memperlemah proses pencepatan penanganan Covid-19. Kalau masyarakat ingin punya ketahanan agar keluar dari krisis kemanusiaa yang panjang, maka harus benar-benar sadar bahwa pandemi Covid-19 bukan sekedar takdir mati begitu saja namun berdanpak sangat 
komplek, sistemik terhadap kelangsungan hidup manusia kedepannya. Sebab yang diserang bukan hanya dari kalangan masyarakat biasa bahkan tenaga medis juga ikut menjadi korban. Bila semakin banyak tenaga medis yang menjadi korban maka akan semakin sulit krisis kemanusiaan akan berakhir. Orang tidak tidak berani melakukan pertemuan secara global atau memasuki daerah yang terinfeksi, investasi juga terhambat dan semuanya akan menjadi pemicu krisis kemanusiaa secara global. Oleh karena itu, MDMC selalu konsisten memandang ini sebagai kasus yang sangat serius yang tidak boleh diabaikan dan tidak boleh diremehkan.

MDMC sampai sekarang dengan tetap memperhatikan protokol kesehatan. Dalam rangka penanggulangan pandemi Covid-19, Muhammadiyah merespon dengan mengeluarkan Maklumat perkembangan Covid-19 di Indonesia, pada tanggal 14 Maret 2020 dengan Nomor: $02 / \mathrm{MLM} / 1.0 / \mathrm{H} / 2020$ tentang Wabah Corona Virus Disease (Covid19). Muhammadiyah sebagaimana dalam Surat Edaran tersebut mengambil kebijakan strategis dalam upaya menangani Covid-19 dengan beberapa langkah-langkah, yaitu:

\section{a) Revitalisasi Ritual Teologi}

Gelobang virus Covid-19 telah mempenaruhi situasi dunia, dari kehidupan normal menjadi kondisi darurat. Setiap individu harus mawas diri dengan tetap memaksimalkan 5M sebagai standar protokol kesehatan, agar virus yang tidak kasat mata ini tidak dapat bermutasi ke mana-mana. Oleh sebab itu, Muhammadiyah mengeluarkan fatwa agar pelaksanaan sholat jamaah dialihkan di rumah masing-masing tanpa harus mendatangi tempat ibadah, seperti pelaksanaan sholat fardu lima waktu. Kendati ibadah sholat fardu itu kewajiban mutlak bagi laki-laki untuk melaksanakan secara berjamaah di masjid. Karena itu, agama memberi kemudahan dengan mengajarkan cara sholat pada saat kegentingan seperti pandemi Covid-19 ini. Kondisi lingkungan semacam ini telah mengubah hukum-hukum teologis dengan mempertimbangan kemaslahatan umat lebih diutamakan daripada sensasi ritus dalam ritual teologi. Bila merujuk pada basis epistemologi teologi, dalam kondisi hujan lebat saja sholat jum'at bisa dipindahkan dari masjid ke rumah. Pandemi Covid-19 ini lebih berbahaya dari sekedar air hujan, karena itu revitalisasi dalam sholat fardu lima waktu dialihkan dari masjid ke rumah masingmasing dengan.

Dalam suasana kebatinan ini, perlu meningkatkan pengetahuan keagamaan dengan metode pendekatan bayani, burhani, dan irfani. Pendekatan bayani merupakan metode pendekatan dengan cara menafsikan teks secara sosiologis. Dalam kasus pandemi Covid-19, sholat di rumah sama mulianya dengan melakukan sholat di masjid saat situasi sosial normal. Dengan menggunakan pendekatan burhani, melaksanakan sholat di rumah masing-masing menjadi lebih utama dan bahkan wajib hukumnya. Karena telah berusaha mencega dan memutuskan mata rantai penularan wabah dengan menghindari kerumunan pada saat menyelenggarakan sholat berjamaah di masjid. Mobilitas manusia antar daerah berbeda zonasi harus menjadi perhatian bersama, karena akan bermuara pada masyarakat di lingkungan masjid sekitar. Dengan kata lain, sebagai muslim yang berkemajuan tidak boleh hanya berpaku pada teks normatif bahwa melaksanakan sholat berjamaah di masjid lebih di utamakan, tapi harus ditafsirkan teks itu dalam konteks sosiologis.

Sedangkan pendekatan irfani, membawa kita pergi pada rasa empati dengan profesi para tenaga kesehatan yang berjibaku di garda terdepan yang 
rawan terpapar dan sudah banyak yang menjadi korban meninggal dunia. Mereka yang telah menjadi korban dalam penanggulangan pandemi Covid-19 ini pulang ke tempat peristirahatan terakhir tanpa di antar kerabat. Dalam kondisi semacam ini, masihkan melaksanakan sholat di masjid hanya untuk menikmati kepuasan dalam ritual ibadah berjamaah tanpa peduli dengan standar protokol kesahatan dan mengabaikan rasa empati pada mereka yang telah gugur dalam tugas kemanusiaan.

Pandemi Covid-19 telah menelan banya korban jiwa, dan untuk menghindari penyebaran selanjutnya, Muhammadiyah berpendapat bahwa dalam ritual sholat jenazah dapat direvitalisasi dengan pelaksanaan sholat gaib dan pelaksanaan takziah dapat diselenggarakan dengan cara daring. Dalam konteks perawatan jenazah dapat dimakamkan tanpa harus dimandikan dan dikafani untuk menghindari kontak langsung dengan korban yang terpapar Covid-19 ini. Hal ini dilakukan agar pihak keluarga dan tenaga medis dapat menghindari penyebaran virus selanjutnya (Surat Edaran PP Muhammadiyah). Berbagai himbauan dan fatwa yang disampaikan khususnya warga Muhammadiyah, untuk menyelenggarakan ibadah sholat di rumah masing-masing. Pengaturan tata sholat ini dilakukan, karena dalam pelaksanaan sholat fardu di masjid dapat berpotensi menjadi kontestasi penularan virus Covid-19. Prinsip ini didasarkan pada teorema menghindari kemudaratan lebih diutamakan daripada mendatangkan maslahat. Sebab perintah agama dalam pelaksanaan ritual keagamaan, agar dimudahkan apalagi dalam kondisi saat seperti ini. Begitu juga dalam konteks pernikahan, untuk menghindari kerumunan orang banyak, Muhammadiyah menilai dalam penyelenggaraan ritual akan nikah hendaknya tetap mengutakam $5 \mathrm{M}$ yang telah ditetapkan pemerintah di dalam berinteraksi dengan orang lain. Sedangkan dalam hal penyelenggaran resepsi pernikahan ditiadakan sampai situasi kondusif dan normal. Hal ini merupakan bagian dari solusi agar penyebaran Covid-19 tidak tidak semakin meluas. Semua ijtihad itu dilakukan MDMC dalam upaya meminimalkan potensi penularan virus Covid-19. Dengan mengacu pada perkembangan informasi penularan virus Covid-19 yang tidak bisa dibendungi, Majelis Tarjih dan Tajdid PP mengambil keputusan yang terkait ibadah dalam situasi pandemi Covid-19.

\section{b) Membatalkan Agenda Strategis}

Dalam upaya memaksimalkan kebijakan physical distancing, seluruh kegiatan persyerikatan dibatalkan mulai dari tingkat pusat sampai ranting serta menunda pelaksanaan agenda wajib. Mukhtamar Muhammadiyah merupakan agenda strategis dan hukumnya adalah wajib yang melibatkan jutaan kader. Pelaksanaan mukhtamar menjadi media konsolidasi serta kontestasi organisasi, evaluasi, perencanaan program dan yang paling penting adalah untuk suksesi kepemimpinan. Karena pandemi Covid19 pelaksanaan mukhtamar Muhammadiyah yang ke-48 dari yang dari awal telah dijadwalkan 1-5 Juli 2020 di Surakarta, ditunda dan akan diselenggarakan pada tanggal 24-27 Desember 2020. Kemudian berdasarkan saran dan pertimbangan dari para anggota Tanwir, memutuskan mukhtamar akan dilaksanakan setelah pelaksanaan haji tahun 2022. Namun, bila keadaan pada tahun 2021 perkembangan Covid-19 dapat dikendalikan, dan dapat dipastikan aman maka pelaksanaan mukhtamar dapat diselenggarakan secara normal, dan akan memberi pertimbangan atau opsi untuk penyelenggaraan mukhtamar 
sebelum tahun 2022.

Perubahan waktu penyelenggaraan mukhtamar yang ke-48 merupakan bentuk dari langkah kebijakan Pimpinan Pusat Muhammadiyah dalam merespons perkembangan Covid-19 di Indonesia. Dengan seluruh masukan dan pertimbangan yang ada, Muhammadiyah menyimpulkan bahwa perkembangan Covid-19 ini berada pada level kedaruratan tinggi. Karena itu, dalam situasi darurat mengutamakan keselamatan dan mempertimbangkan kepentingan orang banyak. Pimpinan Wilayah Muhammadiyah (PWM) di seluruh Indonesia dengan Organisasi Otonom tingkat Pusat melalui rapat pleno secara telekonfrensi pada tanggal 21 Maret 2020, bersepakat untuk menunda pelaksanaan agenda mukhtamar Muhammadiyah. Hal itu dilakukan demi kemaslahatan umat. Di samping itu, keputusan ini dilakukan sesuai dengan rekomendasi dari MCCC yang didukung dengan hasil penelitian para ahli epideminologi tentang perkiraan terkendalinya keadaan darurat nasional.

Selain menggeserkan agenda wajib, Muhammadiyah telah membatalkan rangkaian kegiatan persyerikatan untuk mengefektifkan physical distancing. Pelaksanaan kajian akbar ramadhan tahun 2020 di kampus Universitas Muhammadiyah Yogyakarta (UMY) adalah salah satu contoh agenda persyerikatan yang batalkan. Agenda pengajian ini diikuti oleh seluruh PWM sekaligus agenda konsolidasi gerakan dan kontestasi peneguhan ideologi. Pada Tanwir 19 Juli 2020, Muhammadiyah menegaskan untuk meneruskan jihad kemanusiaan dalam melawan pandemi Covid-19. Bagi Muhammadiyah, pandemi yang memporak-poranda ruang dan keuangan publik ini bukanlah wabah yang sederhana. Muhammadiyah rela mengundurkan waktu pelaksanaan mukhtamar sampai dua kali. Tanwir yang memutuskan pengesahan penundaan mukhtamar itu mengusung tema "Hadapi Covid-19 dan Dampaknya: Beri Solusi Untuk Negeri", merupakan bentuk komitmen Muhammadiyah dalam jihad kemanusiaan melawan pandemi Covid19. Dari awal, Muhammadiyah dan Aisyiyah berkomitmen dengan menunjukan keberpihakannya dalam jihad melawan pandemi Covid-19 ini (Suara Muhammadiyah edisi 15).

\section{c) Rekayasa Teknis Pembelajaran}

Di wilayah pendidikan, MDMC dan MCCC turut aktif dalam mengawal proses penyelenggaraan pendidikan di seluruh amal usaha Muhammadiyah, agar tidak menimbulkan klaster baru. Disamping itu, MCCC juga membuka Layanan Dukungan Psikososial (LDP) Psikolog sebagai edukasi publik dalam merespon perkembangan Covid-19. Layanan kesehatan online yang dibuka secara gratis itu dilakukan untuk mengurangi kepanikan masyarakat terhadap pandemi Covid-19. Layanan psikologi tersebut merupakan konsultasi psikis secara online yang dilayani oleh 60 psikolog Muhammadiyah dan Aisyiyah yang ditugaskan sebagai tempat konsultasi masyarakat yang mengalami kecemasan. Mengingat masih banyak orang yang tidak percaya dan menganggap pandemi Covid-19 ini sebagai konspirasi. Selain itu, pandemi Covid-19 juga merembet ke isu-isu keagamaan, seperti ritual keagamaan yang terhambat oleh kebijakan yang kontra terhadap doktrin keagamaan, sehingga mengharuskan MCCC untuk membuka layanan konsultasi keagamaan.

Sampai saat ini, pandemi Covid-19 belum menunjukan tanda-tanda penurunah. Sebaliknya, eskalasi kurva kematian menunjukan semakin hari semakin progresif. Penutupan kegiatan tatap muka di sekolah atau kampus merupakan akibat dari penerapan 
pemberlakuan kebijakan penerapan protokol kesehatan, kendati menimbulkan tantangan baru yang dihadapi dunia pendidikan selama pandemi berlangsung. Tantangan kualitas pembelajaran dan masa depan pendidikan menjadi keresahan yang dialami oleh Amal Usaha Muhammadiyah (AUM). Secara epidemiologi, rencana penyelenggaran kegiatan tatap muka di sekolah atau di kampus masih mengkhawatirkan. Loncatan kurva pandemi Covid-19 di dalam dunia pendidikan tidak mudah dikendali. Bila akan dilaksanakan maka harus menyediakan peralatan dan perlengkapan pengendali komando kedaruratan, protokol-protokol kesehatan, dukungan keuangan yang cukup, perlengkapan pelaksanaan dan penegakan protokol kesehatan dan tersedianya sumberdaya manusia yang memiliki kompetensi dan terlatih yang bisa dipertanggungjawabkan dalam sistem komando kedaruratan.

Inisiatif pelaksanaan kegiatan pembelajaran atau perkuliahan selama pandemi Covid-19 berlangsung, dikhawatirkan akan menimbulkan krisis yang lebih panjang akibat terjadinya penularan di lingkungan sekolah atau kampus yang menjadi tanggung jawab penuh bagi pimpinan Amal Usaha Muhammadiyah. Dalam situasi pandemi seperti ini, diperlukan inovasi kegiatan pembelajaran diluar kegiatan tatap muka serta adaptasi terhadap kondisi yang dihadapi dengan mengikuti protokol kesehatan dan prosedur pengelolaan kedaruratan. Perguruan tinggi diharapakan untuk lebih terampil dalam melakukan pembelajaran daring yang lebih efektif dengan menggunakan media komunnikasi seperti Google Meet dan Zoom Meeting. Fitur perekam audio dan video dapat membantu perguruan tinggi terutama para dosen untuk dapat merefleksi kembali materi yang telah diajarkan (Grace \& Rianto, 2020).
Muhammadiyah menjadi bagian terdepan dalam penanggulangan pandemi Covid19 di Indonesia dengan tetap menjunjung tinggi nilai-nilai kemanusiaan sebagai gerakan amal ma'ruf nahi munkar. Dalam penanggulangan Covid-19, Muhammadiyah telah banyak mencurahkan energi dan sumber daya yang dicurahkan untuk memulihkan ruang publik, mulai dari penanganan pasien terdampak Covid-19, upaya pencegahan dalam membatalkan laju penularan hingga penanganan dampak sosial ekonomi melalui program ketahanan pangan. Wabah virus Covid19 ini telah mengacaukan proses sistem pembelajaran di lembaga pendidikan dan menimbulkan kesulitan dalam pelaksanaan pendidikan di berbagai lapisan masyarakat.

Dalam kondisi darurat seperti ini, Muhammadiyah lebih mengutamakan pencegahan serta pemulihan kesehatan umat. Oleh sebab itu, seluruh agenda yang membahayakan kesehatan, Muhammadiyah mempertimbangkan kembali secara matang. Menjaga sehat masyarakat itu lebih diutamakan daripada mendatangkan maslahat. Itu sebabnya mengapa kita tidak boleh lengah dalam beraktifitas sebab wabah belum usai. Membererikan edukasi kepada masyarakat, ditengah tuna pengetahuan dan gersang kesadaran Covid-19 menjadi sangat penting. Dalam hal mitigasi, masyarakat harus memiliki kesadaran "sense of crisis" agar dapat mencegah lebih dini potensi penularan virus Covid19 yang lebih besar. Kesadaran masyarakat menjadi bagian penting dalam memutuskan rantai penyebaran virus Covid-19, agar tidak bermuara pada kondisi darurat nasional.

\section{SIMPULAN}

Salah satu ijtihad kemanusiaan MDMC adalah dibentuknya MCCC untuk menanggulangi pandemi Covid-19, 
baik secara medis maupun non-medis yang meliputi relawan distributor alat pelindung diri (ADP), relawan distributor sandang dan pangan, relawan pengemudi dan lain-lain. Kepedulian sosial dan solidaritas ini dapat dimaknai dalam bentuk ijtihad kemanusiaan MDMC dalam menghadapi pandemi Covid-19 di Indonesia. Dalam rangka penanggulangan pandemi Covid-19, Muhammadiyah merespon dengan mengeluarkan Maklumat perkembangan Covid-19 di Indonesia, pada tanggal 14 Maret 2020 dengan Nomor: 02/MLM/1.0/H/2020 tentang Wabah Corona Virus Disease (Covid-19). Muhammadiyah sebagaimana dalam Surat Edaran tersebut mengambil kebijakan strategis dalam upaya menangani Covid-19 dengan beberapa langkah-langkah sebagai berikut: revitalisasi ritual teologi, membatalkan agenda strategis, dan rekayasa teknis pembelajaran. Penelitian lanjutan masih terbuka terutama dari aspek kemanusiaan, keagamaan, pendidikan dan medis, sehingga dapat memperoleh pemahaman yang lebih mendalam tentang ijtihad kemanusiaan MDMC dalam menghadapi pandemi Covid-19 di Indonesia.

\section{DAFTAR PUSTAKA}

Alkaf Muhmmad. (2020). Agama, Sains, dan Covid-19: Perspektif SosialAgama. Maarif. 15 (1), 94-108.

Creswell Jhon W. (2012). Research Design Pendekatan Kualitatif, Kuantitatif, dan Mixed. Yogyakarta: Pustaka Pelajar.

Ervianingsih, Astari Chitra, Zahran Izal, Hurria, Mursyid Murrni, Samsi Al Syahril. (2020). Pencegahan Covid19 dengan pembuatan dan pembagian hand sanitizer di
Universitas Muhammadiyah

Palopo. Indra. 1 (2), 44-48.

Falahuddin. (2020). Respon Muhammadiyah Menghadapi Covid-19. Maarif. 15 (1), 137-151.

Fadly D. Hawangga, Sutama. (2020). Membangun Pemasaran Online dan Digital Branding di Tengah Pandemi Covid-19. Ecoment Global. 5(2), 213-222.

Grace Sandra Chrisnatalia, Rianto Dedi Rahadi. (2020). Komunikasi Digital Pada Pembelajaran Secara Daring Dimasa Pandemi Covid-19. Jurnal Bonanza: Manajemen dan Bisnis. 1(2), 56-65

Habermas, Jurgen. (1989). The Structural Transformation of the Public Sphere. Britain: Polity Press.

Hanafi Yusuf, Saefi Muhammad, Alifudin M. Ikhsan, Nur S. Diyana. (2020). Pandemi Covid-19: Respon Muslim Dalam Kehidupan SosialKeagamaan dan Pendidikan. Sidoarjo: Delta Pijar Katulistiwa.

Hanoatubun Silpa. (2020). Dampak Covid-19 Terhadap Prekonomian Indonesia. EduPsyCouns Jurnal. 2(1), 146-153.

https://nasional.kontan.co.id/news/kemati an-pasien-corona-di-indonesiamencapai-1280-orang-tertinggi-didunia

Husein Bachtiar, Sidipratomo Prijo, Dianita Putri I. Meilia, Mayer G. Christianto. (2020). Tinjauan Etik Prioritas Alat Pelindung Diri (ADP) untuk Profesional Pemberi Asuhan (PPA) Kedokteran dan Kesehatan. JEKI. 4 (2), 47-51. 
Ichsan Muchammad. (2020). Islamic Philanthropy and Muhammadiyah's Contribution to the Covid-19 Control in Indonesia. Afkaruna. 16 (1), 115-129.

Insya' A. Ansori, Ulumuddin M. (2020). Kedudukan Fatwa MUI Dan Lembaga Fatwa Di Indonesia. Jurnal Mahkamah. 5 (1), 38-56.

Izazi Farizah, Kusuma P. Astrid. (2020). Hasil Responden Pengetahuan Masyarakat Terhadap Cara Pengelolaan Temulawak (Curcuma Xantrhorrhiza) dan Kencur (Kaemfaria Galanga) Sebagai Peningkatan Imunitas selama Covid-19 dengan Menggunakan Kedekatan Konsep Program Leximancer. Jurnal of Pharmacy and Science. 5 (2), 93-97.

Junaedi Fajar. (2020). Dinamika Komunikasi di Masa Pandemi Covid-19. Yogyakarta: UMY.

Junaedi Dedi. (2020). Dampak Pandemi Covid-19 terhadap Pasar Modal di Indonesia: Studi Kasus Indeks Saham Komposit (ISHG). Alkharaj. 2 (2), 109-131.

Miharja Marjan, Wiend M. Sakti, Brostito Valentino, Hasan, Sofyan M. Hidayat, Alfredo Yulius, Emilio R. Porwayla, Putra N. Ardhana. (2020). Pembuatan Sabun Cuci Tangan dalam Peran Serta Penanganan Covid-19 Berdasarkan Peraturan Menteri Kesehatan Nomor 62 Tahun 2017 bersama PCM Kramat Jati dan Pemuda Muhammadiyah Kramat Jati Jakarta Timur-DKI Jakarta. INPM. 1 (1), 43-50.
Muchlasin Anif, Suyatno Hempri. (2020). Peran Civil Society dalam Menghadapi Pandemi Covid-19 di Desa Karangtengah Kecamatan Kemangkon Kabupaten Purbalingga. IMEJ. 2 (1), 53-66.

Muryanti. (2020). Kajian Sosiologi Pandemi Covid-19. Sosiologi Reflektif. 5 (1), 113-123.

Suara Muhammadiyah edisi 15 th. Ke105 1-15 Agustus 2020

Surat Edaran Pimpinan Pusat Muhammadiyah, h. 26-29.

Zainab Zilullah Toresano Wa Ode. (2020). Integrasi Sains dan Agama: Meruntuhkan Arogansi di Masa Pandemi Covid-19. Maarif. 15 (1), 231-245. 